\title{
Tinjauan Pelaksanaan Pelepasan Informasi Medis Untuk Keperluan Visum Et Repertum Di Rumah Sakit Singaparna Medika Citrautama
}

\author{
Pina Lapenia ${ }^{1}$, Imas Masturoh ${ }^{2}$ \\ ${ }_{1,2}$ Poltekkes Kemenkes Tasikmalaya \\ vinalapenia53@gmail.com ${ }^{1}$, imas.mth74@gmail.com²
}

\begin{abstract}
Abstrak
Berdasarkan studi pendahuluan di RS Singaparna Medika Citrautama ditemukan adanya keterlambatan penyerahan hasil visum et repertum dan tidak adanya prosedur tetap untuk pelepasan visum et repertum sehingga bagi pemohon dalam hal ini kepolisian dapat menyebabkan terhambatnya penyelidikan. Tujuan penelitian ini adalah untuk mengetahui gambaran proses pelepasan visum et repertum di Rumah Sakit Singaparna Medika Citrautama. Jenis penelitian ini adalah kualitatif dengan pendekatan studi kasus. Subjek penelitian terdiri dari petugas rekam medis, kepala rekam medis dan petugas kepolisian. Analisis data menggunakan analisis tematik. Hasil penelitian ini ditemukan 6 (enam) tema, yaitu surat permintaan visum et repertum yang seringkali terlambat dari pihak kepolisian, ketidaksesuaian prosedur pelaksanaan pelepasan visum dengan SOP dimana surat permintaan tidak diberi disposisi dari direktur rumah sakit, pemeriksaan visum kasus tertentu terkadang tidak dilakukan oleh dokter ahli, tulisan dokter pada pemeriksaan visum kadang-kadang tidak terbaca, pencatatan jenis visum dalam buku ekspedisi tidak dicantumkan, dan terjadinya keterlambatan pelepasan visum. Pelaksanaan pelepasan Visum et Repetum di Rumah Sakit Singaparna Medika Citrautama belum sesuai dengan SOP yang berlaku dan masih terdapat permasalahan keterlambatan dalam pelepasan visum. Disarankan agar dapat meningkatkan pelaksanaan pelepasan visum sesuai SOP melalui sosialisasi dan komitmen kepada semua pihak yang terkait.
\end{abstract}

Kata Kunci : Pelepasan Informasi medis, Visum et Refertum

\begin{abstract}
Based on a preliminary study at the Singaparna Medika Citrautama Hospital, there was a delay in the submission of the results of the post mortem examination and the absence of a fixed procedure for the release of the post mortem report so that the police could cause delays in the investigation. The purpose of this study was to determine the description of the release process of post mortem repertum at the Singaparna Medika Citrautama Hospital. This type of research is qualitative with a case study approach. The research subjects consisted of medical record officers, medical record heads and police officers. Data analysis using thematic analysis. The results of this study found 6 (six) themes, namely the letter of request for post mortem et repertum which is often late from the police, incompatibility of procedures for the implementation of post mortem release with an SOP where the request letter is not disposition from the director of the hospital experts, the doctor's writing on the post mortem examination is sometimes illegible, the recording of the post mortem type in the expedition book is not included, and the delay in post mortem release. The release of Visum et Repetum at the Singaparna Medika Citrautama Hospital is not in accordance with the applicable SOP and there are still problems with delay in post mortem release. It is recommended that it can improve the implementation of post mortem release in accordance with the SOP through socialization and commitment to all parties involved.
\end{abstract}

Keywords: Release of medical information, Visum et refertum

\section{Pendahuluan}

Sistem informasi kesehatan merupakan salah satu bentuk pokok Sistem Kesehatan Nasional (SKN) yang dipergunakan sebagai dasar dan acuan dalam penyusunan berbagai kebijakan, pedoman, dan arahan penyelenggaraan pembangunan kesehatan serta pengembangan berwawasan kesehatan. (Rustiyanto, 2009). Berdasarkan Undang-undang RI Nomor 36 tahun 2009 tentang kesehatan, kesehatan merupakan hak asasi manusia dan salah satu unsur kesejahteraan yang harus diwujudkan 
oleh pelayanan kesehatan. Hal ini membutuhkan campur tangan pelayanan kesehatan agar tercapainya derajat kesehatan masyarakat yang sesuai dengan cita-cita bangsa dengan pelayanan yang efektif, efisien dan terarah. Oleh karena itu, rumah sakit sebagai unit pelayanan kesehatan masyarakat harus memberikan pelayanan medik dan penunjang medik yang bermutu. Salah satu bentuk pelayanan yang diberikan adalah pelayanan administrasi berupa pelayanan rekam medis (Hosizah, 2014).

Rekam Medis sebagai bagian dari pelayanan umum di sebuah Rumah Sakit yang salah satu pelayanannya adalah menyelenggarakan pelepasan informasi isi rekam medis pasien yang sesuai dengan standar yakni berisi informasi lengkap perihal proses pelayanan kesehatan dimasa lalu, masa kini, dan perkiraan dimasa mendatang. (Hatta, 2012). Berdasarkan PerMenKes RI No.269/MENKES/ PER/ III/ 2008 pasal 1 menyatakan bahwa "Rekam Medis adalah berkas yang berisikan catatan dan dokumen tentang identitas pasien, pemeriksaan, pengobatan, tindakan, dan pelayanan lain yang telah diberikan kepada pasien". Rekam Medis memiliki peran dan fungsi yang sangat penting, yaitu sebagai dasar pemeliharaan kesehatan dan pengobatan pasien, bahan pembuktian dalam perkara hukum, bahan untuk keperluan penelitian dan pendidikan, dasar pembayaran biaya pelayanan kesehatan dan terakhir sebagai bahan untuk membuat statistik kesehatan (Hosizah, 2014).

Dokumen rekam medis hanya dapat dikeluarkan berdasarkan kebijakan rumah sakit yang berwenang serta kerahasiaan isinya dikeluarkan berdasarkan izin dari pihak pasien yang bersangkutan, sehingga secara hukum dapat dipertanggung jawabkan. Isi dalam dokumen rekam medis digunakan sebagai sumber data yang dapat dimanfaatkan untuk berbagai keperluan salah satunya visum et repertum. (Setiady, 2009)

Informasi medis bersifat rahasia, maka dalam pelepasan informasi kepada pihak lain (secondary release) sarana kesehatan bertanggung jawab untuk melindungi informasi kesehatan yang terdapat didalam Rekam Medis terhadap kemungkinan hilang, rusak, pemalsuan dan akses yang tidak sah. Rekam Medis hanya dapat dikeluarkan berdasarkan otoritas Rumah Sakit yang berwenang, dan kerahasiaan isinya dikeluarkan berdasarkan izin dari pasien yang bersangkutan, sehingga informasi yang terdapat didalamnya dapat dipertanggung jawabkan. (Hatta, 2010)
Secara umum dapat disadari bahwa informasi yang terdapat dalam rekam medis bersifat rahasia dan harus dijaga kerahasiaannya oleh dokter maupun tenaga profesi kesehatan lainnya. Hal pembukaan rahasia kedokteran dipertegas dalam PerMenKes RI No. 269/MENKES/PER/III/2008 BAB IV Pasal 10 Ayat 2 "Informasi tentang identitas, diagnosa, riwayat penyakit, riwayat pemeriksaan, dan riwayat pengobatan dapat dibuka dalam hal : Untuk kepentingan kesehatan pasien, memenuhi permintaan aparatur penegak hukum dalam rangka penegakan hukum atas perintah pengadilan, permintaan dan atau persetujuan pasien sendiri, permintaan istitusi/ lembaga berdasarkan ketentuan perundang-undangan dan untuk kepentingan penelitian, pendidikan dan audit medis sepanjang tidak menyebutkan identitas pasien." (Hosizah, 2014)

Pelepasan informasi kesehatan dari rekam medis atau yang biasa disebut surat keterangan medis adalah suatu surat keterangan yang dibuat dan ditandatangani oleh staff medis fungsional dan tim medis yang berisi informasi medis sesuai dengan isi berkas rekam medis pasien, ahli waris pasien, institusi pemerintah atau swasta. Surat keterangan medis secara umum dibagi menjadi dua yaitu surat keterangan medis non pengadilan dan untuk pengadilan.

Jenis surat keterangan medis untuk pengadilan adalah visum et repertum. Visum et repertum adalah keterangan yang dibuat oleh dokter forensik atas permintaan tertulis dari penyidik berdasarkan sumpah tentang apa yang dilihat dan ditemukan pada benda yang diperiksa berdasarkan pengetahuan yang sebaik baiknya untuk kepentingan pengadilan. Dalam pembuatan visum et repertum dibutuhkan kerjasama antara dokter forensik dan perekam medis. Untuk itu penerapan etika profesi harus diterapkan dalam kerjasama ini supaya menghasilkan hubungan yang baik antar profesi kesehatan di sarana pelayanan kesehatan (Waluyadi, 2005).

Visum et repertum memiliki peranan yang penting untuk bukti hukum pengadilan. Visum et repertum adalah sebuah kenyataan bahwa masyarakat menghendaki agar setiap orang yang bersalah harus dipidana, sementara yang tidak bersalah tidak harus dihukum (dibebaskan). Logika yang demikian adalah benar adanya baik berdasarkan alasan yuridis konstitusional maupun berlandasakan akal sehat manusia. (Setiady, 2009) 
Pina Lapenia, Imas Masturoh. Tinjauan Pelaksanaan Pelepasan Informasi Medis Untuk Keperluan ....

Penyelenggaraan rekam medis yang baik bukan semata-mata untuk keperluan medis dan administrasi, tetapi juga karena isinya sangat diperlukan oleh individu dan organisasi yang secara hukum berhak untuk mengetahuinya. Pengadilan sebagi salah satu badan resmi secara hukum berhak untuk meminta pemaparan isi rekam medis jika kasus yang sedang ditanganinya membutuhkan rekam medis sebagai alat bukti penyelidikan.

Untuk pelepasan informasi medis tersebut dibutuhkan ketentuan yang mengatur pelaksanaan pelepasan informasi medis ketentuan itu disebut juga dengan prosedur tetap (protap). Prosedur tetap adalah aturan yang mengatur tentang alur atau pedoman kerja untuk penyelenggaran rekam medis rumah sakit. (Huffman, 1994)

Petugas rekam medis harus memahami dan mengerti bagaimana prosedur pemaparan isi rekam medis untuk pengadilan. Peraturan ataupun prosedur tersebut disosialisasikan untuk dilaksanakan oleh pihak-pihak yang bersangkutan dengan pemaparan isi rekam medis, sehingga tidak terjadi kesalahan prosedur dan tidak menimbulkan adanya tuntutan dimasa yang akan datang.

Berdasarkan hasil penelitian Faizal (2010) menyebutkan banyak terjadi ketidaksesuaian terjadi antara protap dan hukum kesehatan diantaranya adalah dalam pelaksanaan visum et repertum, pengekspedisian dilakukan dibagian URMINKES/ unit rekam medis, sedangkan pada prosedur tetap pengekspedisian dilakukan dibagian tata usaha. Oleh karena itu pelaksanaan visum et repertum tidak sesuai dengan prosedur tetap yang sudah ada di rumah sakit. Isi dari prosedur tetap juga belum sesuai dengan hukum kesehatan.

Rumah Sakit Singaparna Medika Citrautama adalah salah satu rumah sakit yang sudah mengadakan pelayanan visum et repertum Seperti kasus Penganiyaan, Kekerasan Dalam Rumah Tangga (KDRT), Kecelakaan, Pemerkosaan, Pencabulan, Persetubuhan, dan lain-lain. Pada tahun 2014-2016 terdapat pelayanan visum et repertum sebanyak 146 kasus yang terdiri dari kasus penganiayaan sebanyak 86 kasus, kasus seksual sebanyak 29 kasus, kasus kecelakaan lalu lintas sebanyak 13 kasus, kasus pencabulan 22 kasus, dan kasus pengeroyokan sebanyak 6 kasus.

Berdasarkan observasi ditemukan adanya keterlambatan pemberian hasil visum et repertum dan adanya tenaga kesehatan yang tidak menjalankan sistem informasi rekam medis sesuai SOP Rumah Sakit. Petugas rekam medis belum memahami alur dan sistem sesuai SOP rekam medis sehingga rekam medis yang dilakukan petugas tidak berjalan dengan baik dan tidak sepenuhnya sesuai SOP.

\section{Metode}

Penelitian ini menggunakan desain penelitian kualitatif dengan pendekatan studi kasus yang dilaksanakan pada tanggal 9 Mei - 11 Juni 2017 di RS Singaparna Medika Citrautama. Subjek penelitian dipilih secara Purposive Sampling yaitu petugas pelepasan informasi rekam medis untuk kepentingan visum sebagai informan 1 , kepala rekam medis sebagai informan 2 dan pihak kepolisian sebagai informan 3 . Teknik pengumpuan data melalui wawancara dan observasi. Analisis data yang digunakan adalah analisis tematik.

\section{Hasil}

\section{Surat Permintaan Pemeriksaan Visum et Repertum yang Seringkali Terlambat dari Pihak Kepolisian}

Surat permintaan pemeriksaan visum yang seringkali tidak diserahkan kepada pihak rumah sakit bersamaan dengan proses pemeriksaan rumah sakit, namun seringkali menyusul di hari berikutnya bahkan 2 hari berikutnya. Hal tersebut tidak sesuai dengan SOP yang ada karena proses pemeriksaan visum dilakukan tanpa adanya surat permintaan, hanya melalui lisan.

Surat permintaan pemeriksaan visum juga seharusnya harus dibawa dan diserahkan langsung oleh pihak kepolisian dan pasien tidak bisa diwakilkan oleh pihak yang lain. Pada pelaksanaanya surat permintaan visum itu diajukan kepada pihak kepolisian setelah proses pelaksanaan pemeriksaan visum itu diproses kemudian diserahkan oleh pihak kepolisian ke bagian rekam medis sebagai administrasi. Hal tersebut dikarenakan surat permintaan visum belum sempat dibuatkan oleh pihak kepolisian.

Surat permintaan visum yang diserahkan ke pihak rumah sakit adalah surat yang ditandatangani oleh kepala kesatuan di polisi misalnya Kasat Reskrim atau penyidik yang menangani kasus tersebut minimal pangkat Aipda

\section{Ketidaksesuaian Prosedur Pelaksanaan Pelepasan Visum dengan Standar Oprasional Prosedur (SOP)}


Berdasarkan SOP yang ditandatangani direktur utama tentang prosedur pelepasan visum et repertum di rumah sakit (Lampiran 5) dalam kebijakannya pada nomor 4.1 polisi datang membawa surat permintaan visum dari kepolisian, nomor 4.2 surat tersebut diberi disposisi dari direktur untuk dibuatkan visum ke bagian rekam medis, nomor 4.3 Petugas rekam medis mencatat dalam buku ekspedisi permintaan visum, dan nomor 4.5 petugas rekam medis meminta dokter yang merawat untuk mengisi informasi yang terkandung dalam berkas rekam medis ke dalam formulir visum.

Pihak kepolisian sebagian besar tidak menyerahkan langsung surat permintaan pemeriksaan visum yang ditujukan ke Direktur Rumah sakit untuk dibuatkan pemeriksaan visum tetapi surat permintaan tersebut langsung dibawa ke bagian rekam medis untuk diperiksa. Pihak polisi bahkan meminta pemeriksaan visum dengan lisan tanpa adanya surat permintaan pemeriksaan visum. Padahal menurut SOP surat permintaan visum diserahkan dan diberi disposisi dari direktur Rumah sakit kepada bagian rekam medis untuk dibuatkan pemeriksaan visum.

Terjadinya ketidaksesuaian prosedur pelaksanaan pelepasan visum dengan SOP (Standar Prosedur Oprasional) yang ada dikarenakan petugas visum tidak mengetahui prosedur seharusnya yang sudah ditentukan oleh pihak rumah sakit pada SOP Pembuatan Visum, kemudian SOP tersebut hanya untuk sekedar ada atau tersedia

Buku yang digunakan dalam pendokumentasian visum di rumah sakit terdiri dari buku register, buku ekspedisi pengambilan, dokumen rekam medis dan pengantar visum. Pada pencatatan permintaan visum tidak dituliskan pada buku permintaan oleh petugas rekam medis dikarenakan pencatatan permintaan dan pengambilan digabungkan pada buku ekspedisi.

\section{Pemeriksaan Visum Kasus Tertentu Terkadang tidak Dilakukan oleh Dokter Ahli}

Dokter yang memeriksa visum sebagian besar dilakukan oleh dokter umum. Apabila memang membutuhkan penanganan yang lebih lanjut, maka dari dokter umum dapat mengkonsultasikan kepada dokter spesialis sesuai dengan keadaan pasien. Tetapi untuk kasus tertentu pembuatan visum seharusnya langsung ditangani oleh dokter spesialis atau ahli seperti kasus kekerasan seksual yang diperiksa oleh dokter obgyn. Pada kenyataanya pemeriksaan visum tersebut di RS Singaparna terkadang dilakukan oleh dokter umum yang ada di IGD

\section{Tulisan Dokter pada Pemeriksaan Visum Kadang- kadang Tidak Terbaca}

Hasil visum yang masih dalam bentuk tulisan tangan dokter akan diketik dan dirapihkan oleh bagian administrasi visum, namun seringkali tulisan dokter tidak terbaca sehingga harus konfirmasi kembali kepada dokter yang bersangkutan. Kemudian setelah selesai, memintakan tanda tangan dokter yang bertanggung jawab terhadap pemeriksaan pasien tersebut

\section{Pencatatan Jenis Visum dalam Buku Ekspedisi}

Buku ekspedisi merupakan buku yang memuat bukti-bukti keluar masuknya hasil visum di rumah sakit. Buku ini biasanya terdiri dari buku penerimaan dan pengambilan hasil visum. Dalam pencatatan buku ekspedisi di RS Singaparna ditemukan tidak dituliskan jenis kasus yang dimintakan hasil visumnya, sehingga jika ada pihak rumah sakit atau pihak lain yang memerlukan data mengenai permintaan dan pengeluaran visum yang di lihat pada buku ekspedisi harus mencari pada dokumen permintaan dan pengeluaran visum satu-persatu.

Pihak rumah sakit akan menghubungi pihak kepolisian atau pemohon apabila hasil visum telah selesai dibuat. Selanjutnya pihak kepolisian mengambil hasil visum tersebut dengan memberikan surat kuasa pengambilan hasil visum yang ditandatangani oleh pasien di atas materai atas persetujuan pasien atau keluarga pasien dalam waktu paling lama 3 hari setelah visum selesai. Dalam pengambilan hasil visum pihak kepolisian harus mengurus administrasi pada bagian administrasi visum terlebih dahulu yaitu mengisi buku ekspedisi pengambilan. Jika kasus tidak untuk kepentingan peradilan (berakhir damai) biasanya hasil visum tidak diambil oleh pihak kepolisian melainkan hanya menjadi arsip rumah sakit.

\section{Terjadinya Keterlambatan Pelepasan Visum}

Pelepasan visum terkadang mengalami keterlambatan dikarenakan dokter spesialis atau ahli tidak ada di tempat, sehingga dokter jaga/dokter umum yang menggantikannya. Pembuatan surat keterangan visum oleh bagian administrasi visum harus menunggu hasil dari verifikasi dokter yang memeriksa, dan apabila 
masih terdapat revisi maka akan menghambat dalam pembuatan dokumen visum karena harus dua kali mengerjakan dokumen visum.

\section{Pembahasan}

\section{Surat Permintaan Pemeriksaan Visum et Repertum yang Seringkali Terlambat dari Pihak Kepolisian}

Surat permintaan visum merupakan syarat utama untuk dilaksanakannya pemeriksaan visum oleh dokter dan yang berhak meminta visum adalah penyidik dengan pangkat polisi yang menandatangani surat permintaan visum minimal berpangkat Aipda. Surat permintaan visum pada umumnya diserahkan bersama pasien/keluarga pasien. Namun pelaksanaan di RS Singaparna Medika Citrautama surat permintaan tidak diserahkan sebelum pemeriksaan visum seringkali diserahkan menyusul di hari berikutnya bahkan 2 hari berikutnya setelah pemeriksaan visum dilakukan. Surat permintaan visum yang diserahkan ke pihak rumah sakit Singaparna Medika Citrautama tidak ada ketentuan yang harus ditandatangani oleh polisi sesuai KUHAP pasal 179 minimal Aipda, tetapi ditandatangani oleh Kasat/penyidik atas nama Kepala Kepolisian Resort Tasikmalaya.

Berbeda menurut Hatta (2009) bahwa syarat pelepasan Visum et Repertum adanya surat permintaan sebagai persetujuan pasien untuk membuka informasi medis dan yang berhak meminta visum adalah penyidik yang merupakan polisi negara tertentu dengan pangkat serendah-rendahnya Pelda. Sedangkan pangkat terendah untuk penyidik pembantu adalah Serda. Di daerah terpencil mungkin saja seorang dengan pangkat Serda diberi wewenang sebagai penyidik karena ia komandan.

Sejalan dengan hasil penelitian yang dilakukan oleh Maria (2014) bahwa di Rumah Sakit dr Cipto Semarang surat keterangan diberikan sebelum pemeriksaan visum dilaksanakan dan pihak yang dapat meminta visum adalah pihak kepolisian/ penyidik. Sedangkan pihak pengadilan tidak dapat meminta langsung kepada pihak rumah sakit tanpa melalui kepolisian/penyidik. Dalam protap sudah sesuai dengan menjelaskan permintaan Visum et Repertum dari kepolisian. Syarat lainnya berkaitan dengan isi hasil Visum et Repertum, yaitu: (a) sesuai dengan kenyataan yang ada pada obyek yang diperiksa, (b) tidak bertentangan dengan teori kedokteran yang telah teruji kebenarannya.
Dalam pelaksanaannya di Rumah Sakit Singaparna Medika Citrautama surat permintaan pemeriksaan visum diserahkan kepada pihak rumah sakit setelah pemeriksaan visum dilakukan bukan sebelum pemeriksaan visum. Hal ini tidak sesuai dengan prosedur tetap yang ada di rumah sakit dikarenakan pihak kepolisian telat memproses surat permintaan pemeriksaan visum tersebut.

\section{Ketidaksesuaian Prosedur Pelaksanaan Pelepasan Visum dengan Standar Oprasional Prosedur (SOP) yang Ada}

Prosedur/alur pelepasan Visum et Repetum menurut SOP yang ada di RS Singaparna Medika Citrautama diawali dengan pasien datang membawa surat permintaan visum dari polisi, polisi menyerahkan surat tersebut untuk diberi disposisi dari direktur untuk dibuatkan visum ke bagian rekam medis. Setelah itu petugas rekam medis mencatat dalam buku ekspedisi permintaan visum, permintaan yang sudah ada disposisinya di cari berkasnya di ruang penyimpanan rekam medis. Setelah itu petugas rekam medis meminta dokter yang merawat untuk mengisi informasi yang terkandung dalam berkas rekam medis ke dalam formulir visum, proses ini diselesaikan maksimal dalam waktu 3 hari. Setelah selesai petugas kepolisian megambil berkas visum ke bagian rekam medis, petugas rekam medis mencatat di buku ekspedisi pengambilan visum. Untuk prosedur/alur pelepasan Visum et Repetum dapat dilihat pada gambar di bawah ini:

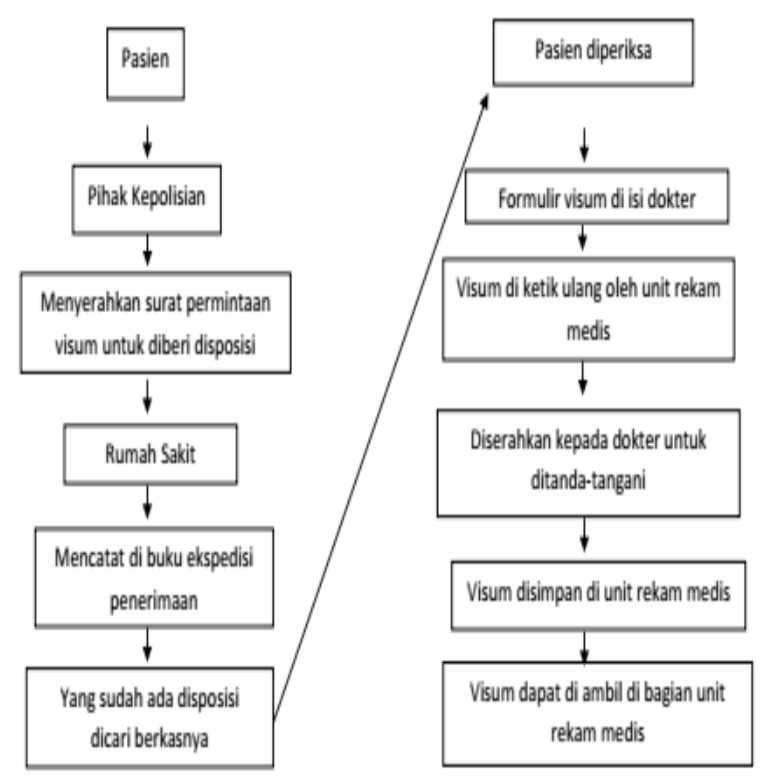

Gambar. 1 Prosedur Pelepasan Visum et Repetum di RS Singaparna Medika Citrautama 
Pelaksanaan pelepasan Visum et Repetum di Rumah Sakit Singaparna Medika Citrautama belum sesuai dengan SOP yang berlaku karena ketidaktahuan petugas rekam medis terhadap SOP dan SOP tersebut hanya untuk memenuhi ketersediaan tanpa ada sosialisasi ataupun komitmen bersama dari semua pihak yang terkait untuk pelaksanaanya. Pada pelaksanaannya diawali dengan pasien/keluarga pasien mendatangi unit IGD untuk melakukan visum, dan dibuatkan visum sementara. Kemudian pasien/keluarga pasien mengajukan surat permintaan ke Polres membawa surat permintaan visum dari kepolisian. Setelah surat permintaan visum diterima lalu diberikan ke bagian rekam medis Rumah Sakit Singaparna Medika Citrautama untuk dibuatkan visum. Dilanjutkan dengan pemeriksaan visum oleh dokter umum dan mengisi formulir visum. Kemudian hasil formulir visum diisi dan diketik ditandatangani oleh dokter yang memeriksa. Setelah hasil visum selesai maka pihak yang meminta visum dalam hal ini pihak kepolisian dihubungi untuk mengambil hasil visum dan dituliskan dalam buku ekspedisi pengambilan visum.

Sejalan dengan hasil penelitian yang dilakukan Novita (2013) tentang tinjauan pelaksanaan prosedur pelepasan Visum et Repetum di RSUD Karanganyar diawali dengan adanya surat pengantar atau permintaan dari kepolisian yang langsung diproses oleh rekam medis seperti melacak nomor dan dokumen rekam medis (apabila pasien lama). Setelah itu diajukan ke dokter untuk melakukan pemeriksaan dengan blangko Visum et Repetum yang disediakan oleh Instalasi rekam medis (dokter membuat konsep). Petugas rekam medis menerima konsep dari dokter untuk selanjutnya diketik dan hasil dikembalikan ke dokter untuk dikoreksi dan ditanda tangani. Setelah tanda tangan dokter selanjutnya ditanda oleh Direktur Rumah sakit. Visum et Repetum diambil oleh pihak kepolisian.

Berbeda dengan penelitian Sinta Puspita Sari (2013) prosedur pelepasan Visum et Repetum di Rumah Sakit Tugurejo Semarang diawali dengan pasien/keluarga pasien memberikan surat permintaan secara tertulis dari pihak kepolisian yang ditujukan kepada Direktur Rumah Sakit. Kemudian Direktur mendisposisikan kepada Wakil Direktur dan selanjutnya Wakil Direktur merekomendasikannya kepada Kepala Bidang Pelayanan untuk kemudian diserahkan ke Kasi Pelayanan Rawat Jalan agar segera ditindaklanjuti Kasi Pelayanan Rawat Jalan mengkoordinasikan secara lisan kepada bagian rekam medis terutama bagian filing untuk mencarikan Dokumen Rekam Medis (DRM) pasien. Setelah DRM ditemukan maka diserahkan kepada kasi pelayanan rawat jalan untuk diserahkan ke dokter yang memeriksa pertama kali (Dokter Umum) agar segera dibuatkan visumnya. Jika memang membutuhkan penanganan yang lebih lanjut, maka dari Dokter Umum dapat mengkonsultasikan kepada Dokter Spesialis sesuai dengan keadaan pasien. Tetapi untuk kasus tertentu pembuatan visum langsung ditangani oleh Dokter Spesialis seperti pada kasus Psikologi. Dalam pengambilan hasil visum pihak kepolisian harus mengurus administrasi pada bagian Administrasi Visum terlebih dahulu yaitu mengisi Buku Register Pengambilan Visum et Repetum yang di dalamnya mencantumkan tanggal pengambilan, nomor Visum et Repetum, nama dokter, nama pengambil, pangkat, NRP, wilayah, tanggal pengambilan dan tanda tangan pengambil.

\section{Pemeriksaan Visum Kasus Tertentu Terkadang tidak Dilakukan oleh Dokter Ahli}

Dalam pemeriksaan visum kasus tertentu di RS Singaparna Medika Citrautama dokter yang memeriksa visum terkadang tidak dilakukan oleh dokter ahli namun dilakukan oleh dokter umum di IGD. Seharusnya pemeriksaan visum itu dilakukan oleh dokter ahli/spesialis seperti kasus kekerasan seksual yang diperiksa oleh dokter obgyn. Sejalan dengan hasil penelitian yang dilakukan Faizal (2014) di RST Bhakti Wira Tamtama bahwa Visum et Repertum dibuat oleh dokter yang pertama kali menangani korban. Pada prosedur tetap siapa yang membuat visum hanya mencantumkan bendel dokumen rekam medis dan formulir Visum et Repertum / jasa raharja diserahkan ke dokter yang pertama kali menangani korban.

Seharusnya pemeriksaan visum itu dilakukan oleh dokter ahli seperti yang tercantum dalam KUHAP pasal 133 ayat 1 , dimana dalam hal penyidik atau kepentingan peradilan menangani seorang korban baik luka, keracunan ataupun mati, yang diduga karena peristiwa tindak pidana, ia berwenang mengajukan permintaan keterangan ahli kepada ahli Kedokteran Kehakiman atau Dokter Ahli Forensik dan atau Dokter lainnya

Tulisan Dokter pada Pemeriksaan Visum Kadang-kadang Tidak Terbaca 
Pina Lapenia, Imas Masturoh. Tinjauan Pelaksanaan Pelepasan Informasi Medis Untuk Keperluan ....

Hasil visum harus di tandatangani oleh dokter yang memeriksa. Dalam mencatat formulir visum, hasil visum yang masih dalam bentuk tulisan tangan dokter akan diketik dan dirapikan oleh administrasi visum dalam mengetik hasil visum dan setelah selesai hasilnya akan dimintakan tanda tangan dokter yang bertanggung jawab terhadap pasien. Hal ini sejalan dengan hasil penelitian Triyo (2015) untuk hasil Visum et Repertum bahwa dokter yang merawat membuat visum dan petugas di IGD memberikan kepada petugas rekam medis untuk diketik setelah itu dikonfirmasi kembali hasil visum yang sudah diketik dan menandatangani hasil visum tersebut.

Dalam pelaksanaannya di RS Singaparna Medika Citrautama penulisan hasil visum dituangkan kedalam tulisan yang diketik. Hal ini sejalan dengan KUHAP pasal 133 ayat (2) mejelaskankan keterangan ahli dibuat secara tertulis dan berperan sebagai alat bukti pengadilan. Dalam penulisan Visum et repertum, dianjurkan untuk dibuat menggunakan komputer. Penulisan dilakukan pada sebuah kertas putih kosong yang harus disertakan dengan adanya kop surat yang berasal dari institusi yang mengeluarkan Visum et Repertum tersebut. Menggunakan singkatan, bahasa asing termasuk bahasa medis tidak dianjurkan dalam pembuatan visum. Jika terpaksa menggunakan bahasa asing, maka keterangan jelas menggunakan bahasa Indonesia harus disertakan. Tulisan dokter pada hasil pemeriksaan visum kadang-kadang tidak terbaca. Sehingga hasil visum yang sudah diketik tersebut sebelum ditandatangani harus di konfirmasikan ke dokter yang memeriksa. Dan apabila ada revisi maka dibuatkan kembali hasil visum yang baru sesuai hasil konfirmasi dokter.

\section{Pencatatan Jenis Visum dalam Buku Ekspedisi}

Pengekspedisian visum dituangkan dalam buku ekspedisi diawali dengan mengisi nama pasien, nomor RM, dan asal permintaan visum. Namun penulisan pada buku ekspedisi tidak dicantumkan jenis kasus visum apa yang dikeluarkan pada saat itu, sehingga jika ada pihak rumah sakit atau pihak lain yang memerlukan data mengenai permintaan dan pengeluaran visum yang di lihat pada buku ekspedisi harus mencari pada dokumen permintaan dan pengeluaran visum satu-persatu, dikarenakan pada buku ekspedisi tidak dicantumkan kasus visum tersebut. Dan pengambilan dapat di ambil oleh pihak kepolisian dengan memberikan surat kuasa pengambilan hasil visum yang yang ditandatangani oleh pasien di atas materai atas persetujuan pasien atau keluarga pasien. Apabila hasil visum tidak diambil oleh pihak kepolisian maka hasil visum tersebut hanya menjadi arsip rumah sakit.

Dalam pelaksanaan ekspedisi di Rumah Sakit Singaparna Medika Citrautama belum sesuai dengan prosedur yang berlaku, karena dalam SOP disebutkan permintaan visum itu harus dicatat dalam buku ekspedisi permintaan sedangkan di Rumah Sakit Singaparna Medika Citrautama petugas rekam medis hanya mencatat pada buku ekspedisi pengambilan.

Dalam pengekspedisian visum penulisan pada buku ekspedisi seharusnya dicantumkan jenis kasus visum namun pada kenyataannya tidak dicantumkan jenis kasus visum apa yang dikeluarkan. Sehingga apabila ada pihak rumah sakit atau pihak lain yang memerlukan data mengenai permintaan dan pengeluaran visum harus dicari pada dokumen permintaan dan pengeluaran visum satu-persatu. Berbeda dengan hasil penelitian Maria (2014 di RS Dr. Cipto Semarang bahwa pengagendaan pada buku ekspedisi mencantumkan pula jenis kasus yang ditangani, identitas korban, identitas yang meminta visum, dan no telepon pihak yang dapat dihubungi.

\section{Faktor Keterlambatan Pelepasan Visum di Rumah Sakit}

Pelepasan visum terkadang mengalami keterlambatan dikarenakan dokter spesialis yang memeriksa tidak ada di tempat, sehingga dokter jaga/dokter umum dapat menggantikan pemeriksaan visum dan mengkonfirmasikan ke dokter spesialis. Apabila dokter ahli/spesialis tersebut tidak ada maka harus menunggu sampai dokter tersebut datang ke rumah sakit dan menandatangani hasil visum pasien. Tidak hanya itu pencatatan petugas rekam medis masih ditemukan tidak singkronnya tulisan hasil visum dokter yang memeriksa dengan pemahaman petugas rekam medis

Hal ini sejalan dengan hasil penelitian yang dilakukan Triyo (2015) untuk hasil Visum et Repertum dimana harus dokter yang merawat yang menandatangi, apabila dokter sedang berada diluar kota atau dokter tersebut tidak ada ditempat, maka hasil visum dikomunikasikan kembali dengan dokter yang menggantikannya sehingga pembuatan surat keterangan visum maupun surat keterangan lainnya harus menunggu hasil dari verifikasi dokter spesialis. Dalam pelaksanaanya di Rumah Sakit Medika 
Citrautama pelepasan Visum et Repertum kadangkadang terjadi keterlambatan dikarenakan dari proses pemeriksaan dan menginput data hasil visum oleh petugas rekam medis memerlukan waktu dan jadwal dokter yang tidak menentu. Ketika ada permintaan visum dan dokumen telah siap tetapi jadwal dokter yang memeriksanya tidak ada untuk menandatangani berkas rekam medisnya maka berkas tersebut belum bisa diambil oleh pihak kepolisian. Dan apabila ada revisi juga menghambat dalam pembuatan dokumen visum karena harus dua kali mengerjakan dokumen visum.

Keterlambatan pelepasan visum dari rumah sakit berdampak pada pelayanan terhadap pasien menjadi terhambat, pembuatan laporan serta pengajuan klaim menjadi terlambat. Dalam kasus pengadilan menghambat proses hukum yang sedang dijalani.

\section{Simpulan}

Pelepasan visum di RS Singaparna Medika Citrautama mengalami keterlambatan dikarenakan dokter spesialis yang memeriksa tidak ada di tempat, sehingga dokter jaga/dokter umum menggantikannya dan mengkonfirmasikan ke dokter spesialis, serta tidak terbacanya tulisan hasil visum dokter sehingga harus dilakukan revisi yang berulang kali.

\section{Daftar pustaka}

Hamdani. Njowito. (2007). Ilmu Kedokteran Kehakiman. Jakarta: Gramedia Pustaka Utama

Hatta, Gemala R. (2012). Pedoman Manajemen Informasi Kesehatan di Sarana Pelayanan Kesehatan. Jakarta: UI Press
Hosizah. (2014). Kumpulan Peraturan Perundangan Rekam Medis dan Informasi Kesehatan (Manajemen Informasi Kesehatan). Yogyakarta: aptiRMIK Press

Huffman, Edna K, RRA. (1994). Health Information Managemant, Tenth Edition, Berweyn, Illinois Physicians' Record Company

Natara, Inovi Maria (2014). Tinjauan Pelaksanaan Prosedur Pelepasan Informasi Medis untuk Keperluan Visum et Repertum dari Aspek Teori di Rumah Sakit Pantiwilasa Dr Cipto Semarang Tahun 2014. Jurnal Visikes - Vol. 12 / No. 4 / Oktober 2010

Novita. (2013). Analisis Pelaksanaan Visum et Repertum di RSUD Karanganyar. Jurnal Manajemen Informasi Kesehatan Indonesia, ISSN:2337-585X,Vol 1 No 2 Oktober 2013

Rachman, Faizal. (2010). Tinjauan Pelaksanaan Prosedur Pelepasan Informasi Medis untuk Keperluan Visum Et Repertum dari Aspek Teori di RST Bhakti Wira Tamtama Semarang. Jurnal Visikes - Vol. 9 / No. 1 / April 2010

Rustiyanto, Ery. (2009). Etika Profesi Perekam Medis dan Informasi Kesehatan. Yogyakarta: Graha Ilmu.

Setiady. Tolib. (2009). Pokok-Pokok Ilmu Kedokteran Kehakiman. Bandung: Alfabeta.

Soeparmono,R.(2012).Keterangan Ahli dan Visum et Repertumm dalam Aspek Hukum Acara Pidana. Bandung: Mandar Maju

Rachmadi, Triyo. (2010). Pelepasan Informasi Rekam Medis Kepada Pihak Ketiga di Rumah Sakit Muhammadiyah Sruweng. Jurnal Visikes - Vol. 11 / No. 2 / April 2014 